\title{
Review
}

\section{Foucault's futures: A critique of reproductive reason}

\author{
Penelope Deutscher \\ Columbia University Press, New York, 2017, 280 pp., \\ ISBN 978-0231176408
}

Contemporary Political Theory (2018) 17, S212-S215. https://doi.org/10.1057/s41296017-0172-5; published online 13 November 2017

Penelope Deutscher's Foucault's Futures: A Critique of Reproductive Reason is an invaluable and innovative text that joins queer theory, critical theory, biopolitics, and feminist and critical race studies around a central preoccupation: procreation. While the text is in some sense recuperative of the role of procreation in Foucault's thinking, it deliberately moves beyond the 'biopolitical hypothesis' that ties procreation to the maximization of life. The book compels the reader to imagine a 'thanatopolitical hypothesis' as well, where women become understood as responsible for multiple forms of death and decline in their procreative capacity. The practices of women (including abortion) and the variable configurations of women's lives (including those associated with race, age, class, and nationality) mark particular women legible or illegible as worthwhile reproductive subjects.

One of the most exciting prospects of the book is methodological. Deutscher stages encounters between disparate theorists, all of whom have dialogued with Foucault's work. Instead of engaging in the mode of critique, she explores the 'suspended reserves' to be found in the work of each theorist. Deutscher finds the concept of suspended reserves in an essay by Jacques Derrida, where he returns to Foucault's History of Sexuality, Volume 1, through a question 'that it keeps in reserve in its unlimited potential ... in suspense, holding its breath' (Derrida, quoted p. 28). Omissions in theories or disagreements between theorists no longer serve as fodder for negative critique and instead become fecund. Instead of serving as an arbiter between theoretical interpretations, the text is a generator of conceptual possibilities that demonstrate both the richness of reproductive politics as an object of study and the richness of contemporary critical theory.

The methodological innovation of the text produces a potential barrier of entry for anyone who is not already well-versed with Deutscher's interlocutors. Because the book is not invested in close reading or critique of each of its theoretical fellowtravelers, a reader who is not already familiar with Edelman's sinthomosexual, Esposito's immunity paradigm, or Butler's precarious life, for instance, may find

(C) 2017 Macmillan Publishers Ltd., part of Springer Nature. 1470-8914 Contemporary Political Theory Vol. 17, S4, S212-S215 www.palgrave.com/journals 
the treatment of each too brief to fully appreciate how these conceptual foundations interlock in creating new theoretical avenues. I found my experience of the book was enriched by having its companion texts by my side. For those who can find themselves in scholarly conversation with these authors, the experience of reading the book is transformative.

Reproductive, biopolitical, and thanatopolitical considerations unite the book, but the text can be split between two main theoretical valences. The first, third, and fourth chapters are centrally concerned with thinking about the relation of sexual difference to biopolitics and, in turn, thanatopolitics. In the first chapter, Deutscher sets up an encounter between Foucault and Derrida to accomplish two tasks. First, she argues that there are resources within Foucault's description of the dehiscence of power that ought to help readers resist Derrida's critique of Foucault's ostensibly rigid periodization of sovereign power and biopower. This insight aids in the second task - to use biopower to enrich Derrida's work on the death penalty and to use Derrida's thinking on sexual difference to enrich the concept of biopower. This elaboration points to the possibility of thanatopoliticized reproduction, where women who are understood as threats to that reproductive future become associated with the capacity of death as well as life.

The third and fourth chapters extend both of these insights. The third chapter's rereading of The History of Sexuality, Volume I, restores attention to the importance of procreation and the family through a Derridean concern for sexual difference. While Foucault describes sex as the 'pivot' of biopower, where the intensification of disciplining the body is coupled with the regulation of populations, Deutscher describes procreative sex as the 'hinge' of the 'mechanisms of power addressing themselves to life and those mechanisms of power addressing themselves to sex or sexuality' (p. 77). Once we ask the question of sex difference, Deutscher also helps us recognize how sovereign power and biopower come to coexist in the familial form. Through expert knowledges of parenting, women become differentiated between good and bad mothers, and thus 'the mother is individuated and becomes a vector of the disciplines in tandem with the child' ( $\mathrm{p}$. 85). The father, by contrast, becomes individuated through sovereign power, in the power of domination in the family.

The ability to think of sovereign and biopower together sets the stage for the consideration of Roberto Esposito's and Giorgio Agamben's work on power and an elaboration of thanatopolitical reproduction in Chapter 4. Using Esposito's insight that biopower produces both the desire to control life and the means to create uncontrollable death, Deutscher brings sex difference and reproduction to the fore to demonstrate how both aspects come together in thanatopoliticized reproduction. This redescription of biopolitics as a gendered encounter with death sets the stage for an encounter with Agamben. Deutscher pays special attention to Agamben's description of the sovereign capacity to create anomic spaces that suspend rights. The capacity of the law to suspend itself is intensified in the context of reproductive

(C) 2017 Macmillan Publishers Ltd., part of Springer Nature. 1470-8914 Contemporary Political Theory $\quad$ Vol. 17, S4, S212-S215 S213 
law. Abortion rights are an 'inverted exception,' where abortion's illegality is assumed such that legal abortions are almost always 'an exception to its own illegality' (p. 126), e.g., legal exceptions for rape or a mother's health. Furthermore, women are positioned as pseudo-sovereigns over the fetus, understood to control fetal life but whose control provokes anxiety about the misuse of that control. Women as the bearers of reproductive life, then, are always at risk of the sovereign suspension of reproductive rights, exposing them to harm and violence, in part because they are also understood as a potential source of harm and violence to the fetus requiring coercion, punishment, or sanction.

The second and fifth chapters are more centrally concerned with the relation between women, fetuses, and unintelligibility. Lee Edelman's reproductive futurism and sinthomosexual frame the second chapter. Reproductive futurism invests in an imaginary Child to situate the future as a necessary continuation of what already is. As such, those who are challenges to the reproductive order become positioned as antisocial threats. Edelman figures the sinthomosexual as anti-sociality and conceptualizes queer negativity as that which eschews restorative politics where queer life becomes reproductive (as with claims to gay adoption or gay marriage). Deutscher has the reader consider the possibilities of a queer negative abortion politics, the female sinthomosexual, and the relationship between the fetishized fetus and the Ideal Mother. Following Edelman's desire to make a space for the antisocial queer, Deutscher wants to make room for 'antisocial feminine irresponsibility' (p. 57) as part of abortion politics. Here, she concludes, 'An important resistance to calculability is also shared by queer politics and the politics of abortion' (p. 59).

Deutscher does not end with resistance to calculation; the last line of the book posits the question, 'can we calculate' (p. 190)? The question of calculability reemerges in the fifth and final chapter through Butler's precariousness. This chapter is a particular marvel of Deutscher's facility with pushing against conventional reproductive politics. While she frames the chapter with the figure of the fetus, Deutscher notes that the fetus as precarious life is not all that instructive; a fetus is not sufficiently made as a social subject such that it can be vulnerable to the violence of desubjectivation. But, Deutscher argues, once the fetus is introduced politically, another subject is made radically more vulnerable to desubjectivation: women. In the presence of the fetus, a woman becomes a 'responsible decision maker' and as such, becomes subject to normative regimes of correct decision making and proper ethical narration. Of course, not all women are situated such that they can be understood as the responsible individual decision maker, but all are rendered potentially unintelligible as ethical reproductive subjects, including transnational surrogate mothers or women seeking illegal abortions. Alongside the female sinthomosexual from Chapter 2, we are presented alternative subjectivities that are foreclosed by the normalizing force of the fetus. In the face of these subjectivities, Deutscher struggles with reproductive rights as a 
kind of right that we 'cannot not want' (quoting Wendy Brown, p. 176). Along with the fetus whose life takes on different meanings, given the contexts of its presence (surrogacy, abortion, miscarriage, etc.), reproductive rights require confronting the question of calculation beyond sheer resistance. Thus, the book ends not with an answer but another opening for us to think with the suspended reserves that remain obscure in Deutscher's own work.

This opening for the reconsideration of reproductive rights, beyond the ethical calculations of reproduction, is one suspended reserve of Deutscher's own text. Is it possible for the rights-bearing individual to reconfigure biopolitical and thanatopolitical reproduction? In part because Deutscher resists taking theoretical sides, the reader does not get a sense of how she would navigate potential critical alternatives to this question. But as an invitation to grapple with the centrality of reproduction in modern political orders, Deutscher's book serves as a crucial resource.

Claire McKinney

College of William \& Mary, Williamsburg, VA 23185, USA cmckinney@wm.edu 